\title{
The Syntax and Pragmatics of Language Contact: a Case Study of Andean Spanish
}

Antje Muntendam

Middlebury College

In the field of language contact, there has been a discussion about the nature of crosslinguistic transfer. The question is what can be transferred from one language to another. One position is that syntactic transfer is possible. Thomason and Kaufman (1988) argue that "anything can be transferred from any language to any other language" (Thomason \& Kaufman 1988: 14) (see also Thomason 2001, 2008). The other position is that syntax is relatively impermeable to influence from another language. Prince $(1988,1992,1998)$ and Silva-Corvalán $(1993,1994,1998,2008)$ argue that transfer is often limited to a transfer of pragmatic uses. In their view, direct syntactic transfer is uncommon.

The issue has not been resolved, that is there seems to be support for both hypotheses. To resolve the issue we need data that allow us to separate syntactic issues from pragmatic issues. In this paper, I present a case study of transfer of word order in Andean Spanish, focusing on the difference between syntax and pragmatics. I argue that there has been an influence from Quechua in Andean Spanish word order phenomena. Specifically, I propose that Andean Spanish and Standard Spanish are syntactically identical, but that there has been a transfer of pragmatic uses from Quechua into Andean Spanish. The study has implications for theories of language contact and syntax.

While Standard Spanish has basic order SVO, in Andean Spanish the object frequently appears in preverbal position, resulting in alternative orders (e.g. OVS) (see (1)).

(1) 'Al gallo come el zorro.'

To the rooster eats the fox

'The fox eats the rooster'

Previous studies have attributed this phenomenon to an (indirect) influence of Quechua, where the object typically precedes the verb (Ocampo \& Klee 1995, Camacho 1999), but they do not discuss in detail which linguistic properties have been transferred. The alternative orders are also possible in Standard Spanish, but in Standard Spanish fronted elements encode topic/focus. Since focus fronting could explain the high frequency of preverbal objects in Andean Spanish, we must determine whether focus fronting in Andean Spanish has the same properties as in Standard Spanish. Following Prince (1988, 1992, 1998) and Silva-Corvalán (1993, 1994, 1998, 2008), the hypothesis is that the transfer is restricted to pragmatics, i.e. the syntactic structure of focus fronting in Andean Spanish is identical to that of focus fronting in Standard Spanish.

The main syntactic properties of focus fronting in Standard Spanish are its sensitivity to weak crossover effects and long distance movement (Rizzi 1997). I designed experiments to test for these properties in Spanish and Quechua. In addition, I created an experiment on questionanswer pairs to study the pragmatics of focus in Spanish and Quechua. The results reveal that not the syntactic structure is transferred but rather the pragmatic uses.

The data for the study come from naturalistic recordings of Spanish of 33 bilingual adult speakers of Quechua and Spanish from Bolivia and Ecuador, and picture-story tasks and acceptability-judgment tasks in Spanish (15 subjects) and Quechua (8 subjects), which were conducted in Bolivia and Ecuador. For comparison, I collected data from a group of 12 
monolingual Spanish subjects. For the picture-story and acceptability-judgment tasks, I elicited judgments on weak crossover, long distance movement, and question-answer pairs.

The results of the study on weak crossover reveal that focus fronting in Standard Spanish and Andean Spanish leads to weak crossover effects (see (2)):

(2) $\left[\mathrm{F}\right.$ A cada niño $\mathrm{i}_{\mathrm{i}}$ trajo $\mathrm{su}_{\mathrm{i}}$ madre a la escuela $\mathrm{t}_{\mathrm{i}}$. [F To every child ${ }_{i}$ ] brought his ${ }_{i}$ mother to the school $t_{i}$. 'His mother brought every child to school.'

The sentence in (2) is an example of a weak crossover configuration. The quantified phrase (QP) a cada niño, 'to every child', undergoes A'-movement, crossing the co-indexed pronoun $s u$, 'his'. The QP c-commands the pronoun and the trace, that is both are interpreted as variables bound by the QP. The pronoun does not c-command the trace, giving rise to a (weak) crossover violation. All of the subjects for Standard Spanish and 73.3\% of the subjects for Andean Spanish displayed weak crossover effects. In Quechua, focus fronting does not lead to weak crossoverthe Quechua equivalent of (2) is grammatical, according to all of the subjects.

The results of the study on long distance movement show that both Andean Spanish and Standard Spanish allow for long distance movement of the object and the subject (see (3) and (4)), but restrict VP fronting (see (5)).

(3) [F Las llamas $\mathrm{i}_{\mathrm{i}}$ ] cree la mujer [CP que lleva el hombre $t_{i}$. [F The llamas $\left.{ }_{i}\right]$ thinks the woman that takes the man $\mathrm{t}_{\mathrm{i}}$.

'The woman thinks the man takes the llamas.'

(4) $\left[\mathrm{F} E 1\right.$ niño $\mathrm{i}_{\mathrm{i}}$ ] cree el maestro [CP que lee el libro $\mathrm{t}_{\mathrm{i}}$.

$\left[\mathrm{F}\right.$ The boy $\mathrm{y}_{\mathrm{i}}$ ] thinks the teacher that reads the book $\mathrm{t}_{\mathrm{i}}$

'The teacher thinks the boy reads the book.'

(5) $*\left[{ }_{F}\right.$ Estudia $\left._{i}\right]$ cree la madre [CP que el niño $\left.t_{i}\right]$. [F Studies $_{i}$ ] thinks the mother that the child $t_{i}$

'The mother thinks the child studies.'

Fifty percent of the subjects for Standard Spanish and 50\% of the subjects for Andean Spanish accepted long distance movement of the object, whereas $25 \%$ of the subjects for Standard Spanish and 33.3\% of the subjects for Andean Spanish accepted long distance movement of the subject. None of the subjects for Standard Spanish and Andean Spanish accepted long distance movement of the VP. The Quechua data furthermore reveal that in this variety of Quechua long distance movement is not possible. The Quechua equivalents of (3)-(5) are unacceptable: none of the subjects accepted long distance movement of the subject, the object or the VP. The data thus show conclusively that Quechua and Andean Spanish have focus fronting, but that in Quechua focus fronting is not sensitive to weak crossover effects and does not allow for long distance movement. This indicates that there is no syntactic transfer from Quechua into Andean Spanish.

There is, however, a transfer of pragmatic uses from Quechua into Andean Spanish. A quantitative analysis of the naturalistic data shows that preverbal objects are relatively frequent in Andean Spanish. The order OV accounts for 18.5\% of the sentences in the Andean Spanish naturalistic data. To compare, Ocampo (1994) found only $7.9 \%$ OV in the speech of 21 middle- 
class speakers from Buenos Aires. A chi-square test shows that the difference between the two varieties of Spanish is significant $\left(\chi^{2}(1, \mathrm{~N}=54)=40.79, p<.0001\right)$.

Moreover, a qualitative analysis of the naturalistic data shows that in Andean Spanish preverbal objects are used in more contexts than in Standard Spanish, for instance in answer to wh-questions with the focus on the object (see (6)).

(6) R: ¿Qué tipo de instrumento toca?

'What type of instrument does he play?'

S: Clarinete toca. $(\mathrm{OV})$

'He plays the clarinet.'

Since question-answer pairs are not frequent in the naturalistic data, I created an elicitation study on question-answer pairs. The questions in (7) elicit answers with the focus on the sentence (Q1), the focus on the subject (Q2), the focus on the VP (Q3), and the focus on the object (Q4). After giving a spontaneous answer (based on a series of pictures), the subjects judged the acceptability of the sentences in (8) in answer to the questions in (7).

(7) Q1: ¿Qué pasa? (sentence focus)

'What happens?'

Q2: ¿Quién corta la soga? (focus on the subject)

'Who cuts the rope?'

Q3: ¿Qué hace el loro?

'What does the parrot do?

Q4: ¿Qué corta el loro? (focus on the object)

'What does the parrot cut?'

(8) a. El loro corta la soga (SVO).

'The parrot cuts the rope'

b. El loro la soga corta. (SOV)

c. La soga el loro corta. (OSV)

d. La soga corta el loro. (OVS)

e. La soga la corta el loro. (O-clitic-VS)

f. Corta el loro la soga. (VSO)

g. Corta la soga el loro. (VOS)

The results show that in Andean Spanish preverbal objects are more frequent and are used in more contexts than in Standard Spanish. In Standard Spanish, there is a correlation between preverbal objects and focus; the orders OVS and OSV were accepted more frequently in answer to questions with a focus on the object. In Andean Spanish, however, there is no correlation between preverbal objects and focus: sentences with a preverbal object (e.g. OSV and OVS) were accepted frequently in answer to all of the questions in (7). Importantly, in Andean Spanish sentences with preverbal objects are also used when the object is not focused, that is preverbal objects have a more general use in Andean Spanish than in Standard Spanish. The results furthermore show that in Quechua there is no correlation between OSV and focus on the object: the order OSV was accepted frequently in answer to all of the questions in (7). The data show convincingly that there has been a pragmatic change in Andean Spanish under influence of Quechua. 
To conclude, syntactically Andean Spanish is identical to Standard Spanish, as shown by the data on weak crossover and long distance movement. This indicates that there has been no syntactic transfer from Quechua into Andean Spanish. In Andean Spanish, however, fronting is not as restricted as in Standard Spanish, which indicates that there has been a change in the pragmatic function of preverbal objects in Andean Spanish under influence from Quechua. The results robustly support only one hypothesis, that is that there has been a transfer of pragmatic uses but not a direct syntactic transfer. The study lends support to studies by Prince (1988, 1992, 1998) and Silva-Corvalán $(1993,1994,1998,2008)$ who argue for a pragmatic transfer.

\section{References}

Camacho, J. 1999. 'From SOV to SVO: the grammar of interlanguage word order' Second Language Research 15(2): 115-132.

Ocampo, F. 1994. 'The word order of two-constituent constructions in spoken Spanish.' In Dowing, P. and Noonan, M. (eds.) Word order in discourse, Amsterdam/ Philadelphia: John Benjamins, 425-447.

Ocampo, F. \& Klee, C. 1995. 'Spanish OV/VO word order variation in Spanish-Quechua bilingual speakers.' In Silva-Corvalán, C. (ed.) Spanish in four continents: studies in language contact and bilingualism. Washington DC: Georgetown University Press, 71-82.

Prince, E. 1988. 'On pragmatic change: the borrowing of discourse functions.' Journal of Pragmatics 12: 505-518.

Prince, E. 1992. 'On syntax in discourse, in language contact situations.' In Kramsch, C. and McConnell-Ginet, S. Text and context: Cross-disciplinary perspectives on language study, 98-112.

Prince, E. 1998. 'The borrowing of meaning as a cause of internal syntactic change.' In Schmid, M., Austin, J. and Stein, D. (eds.) 1998. Historical Linguistics 1997: Selected papers from the 13th International Conference on Historical Linguistics, Düsseldorf, 10-17 August 1997. Amsterdam, Philadelphia: John Benjamins, 339-62.

Rizzi, L. 1997. 'The fine structure of the left periphery', In Haegeman, L. (ed.) Elements of Grammar, Kluwer Academic Publishers, The Netherlands, 281-337.

Silva-Corvalán, C. 1993.' On the permeability of grammars: evidence from Spanish and English contact' In Ashby, W., Mithun, M, Perissinotto, G. and Raposo, E. (eds.) Selected papers from the $21^{\text {st }}$ symposium on Romance Languages. Amsterdam: John Benjamins Publishing Company, 19-43.

Silva-Corvalán, C. 1994. Language contact and change: Spanish in Los Angeles. (Oxford Studies in Language Contact). Oxford: Clarendon Press.

Silva-Corvalán, C. 1998. 'On borrowing as a mechanism of syntactic change.' In Schwegler, A., Tranel, B. and Uribe-Extebarria, M. (eds.) Romance linguistics: Theoretical perspectives. Amsterdam: John Benjamins, 225-246.

Silva-Corvalán, C. 2008. 'The limits of convergence in language contact.' Journal of Language Contact, Thema 2: 213-224.

Thomason, S. and Kaufman, T. 1988. Language contact, creolization, and genetic linguistics. Berkeley, Los Angeles, London: University of California Press.

Thomason, S. 2001. Language contact: an introduction. Edinburgh and Washington, DC: Edinburgh University Press, Georgetown University Press.

Thomason, S. 2008. 'Social and linguistic factors as predictors of contact-induced change.' Journal of Language Contact, Thema 2: 42-56. 